\title{
The Effect of Innovation Types on the Performance of Small and Medium-Sized Enterprises in the Sekondi-Takoradi Metropolis
}

\author{
Francis Boachie-Mensah \\ Department of Management Studies \\ University of Cape Coast. Ghana \\ Innocent S. K. Acquah \\ Department of Management Studies \\ University of Cape Coast. Ghana
}

\begin{abstract}
Innovativeness has been touted as one of the fundamental instruments of growth strategies to enter new markets, to increase the existing market share and to provide the company with a competitive edge. Despite this acknowledgement, there is lack of research into how innovation contributes to the performance of small and medium sized enterprises. The aim of this study was to investigate the influence of innovation on organisational performance of small and medium-sized enterprises (SMEs) in the Sekondi-Takoradi metropolis. The research design used was survey research design whilst the research approach was quantitative research approach. Simple random sampling technique was used to collect data from 243 owners/owner managers of SMEs in the Sekondi-Takoradi Metropolis through self-administered questionnaires. Partial least squares (PLS) structural equation modelling (SEM) was used to test the hypotheses postulated. The study revealed that all four different types of innovation significantly influence organisational performance positively, except the product innovation/organisational performance relationship, which was positive but not significant. The results also suggest that innovation accounted for more than fifty one percent of the variation in organisational performance. It was, therefore, recommended that managers of SMEs pay critical attention to the implementation of innovation activities in their firms due to its positive impact of performance.
\end{abstract}

Keywords: Innovation, organisational performance, small and medium-sized enterprises

\section{INTRODUCTION}

Innovativeness has been touted as one of the fundamental instruments of growth strategies to enter new markets, to increase the existing market share and to provide the company with a competitive edge. Motivated by the increasing competition in global markets, companies have started to grasp the importance of innovation, since swiftly changing technologies and severe global competition rapidly erode the value added of existing products and services (Gunday, Ulusoy, Kilic \& Alpkan, 2011). Thus, innovations constitute an indispensable component of the corporate strategies for several reasons such as to apply more productive manufacturing processes, to perform better in the market, to seek positive reputation in customers' perception and as a result to gain sustainable competitive advantage. Innovation is, therefore, a complex concept, because of its multidimensionality. 
In a business environment characterized by rapid and disruptive changes, variety of customer requirements and international competition, organisations have to acquire new technological capabilities and explore new business processes in order to stay profitable in the long run (Vanhaverbeke \& Peeters, 2005). Therefore, innovation that is able to meet customer requirements and introduce products or processes has become one of the most important issues for firms. It is often linked with creating a sustainable market around the introduction of new and superior product or process (Carayannis \& Gonzalez, 2003). In short, it can be concluded that firms are more competitive with innovation (De Jong \& Vermuelen, 2006).

Innovation also plays an important role in developing the economy, in expanding and sustaining the high performance of firms, in composing industrial competitiveness, in improving the standard of living and in creating a better quality of life (Gopalakrishnan \& Damanpour, 1997). Innovation and its activities in small and medium-sized enterprises (SMEs) have also been of interest to academics (Cosh \& Hughes, 2000). However, studies about innovation management in SMEs are few compared with similar studies on large firms (Cagliano \& Spina, 2002; De Toni \& Nassimbeni, 2003).

Previous studies have argued that, because of their nature, SMEs, particularly those operating in manufacturing, electronics, engineering and general high technology industries, are able to undertake radical innovation more easily than large firms, and that introducing pioneering products is an important entrepreneurial activity and the lifeblood of SMEs (Sirmon, Hitt, Ireland \& Gilbert 2011). However, this is not a fact without refute. Some argue that while a small firm in any of these industries may have high research and development intensity (R\&D/sales), a larger firm with more slack can actually devote more resources to R\&D.

\section{Statement of the problem}

Following from the resource based theory and the shared value theory, innovation is seen as a fundamental variable that influences the performance of SMEs (Gunday et al., 2011; D'Angelo, 2012; Al-Ansari et al., 2013). The significance of this claim to SMEs in the Sekondi-Takoradi metropolis of Ghana remains unclear for three major reasons. To begin with, the formulation, testing, development as well as a bulk of the research on the resource based theory/shared value theory and innovation were mainly carried out among large firms in the developed North American, European, and recently, Asian countries (Al-Ansari et al., 2013), whilst the relationship between the types of innovation has been overlooked (Gunday et al., 2011).

The above implies the presence of a gap in the research concerning the role of innovation in the performance of SMEs in emerging economies, like Ghana. This obviously is an impediment, since firm size and national culture have been acknowledged as mediating the influence of innovation on performance (Al-Ansari et al., 2013). The final deficiency relates to the obvious restriction of the types of innovation in these studies to product innovation and process innovation, ignoring other types of innovation such as marketing innovation and organisational innovation. This situation portrays a deficient representation of the true as well as full effect of innovation on the performance of SMEs. This study, therefore, sought to fill this gap by using partial least squares structural equation modelling to examine the effects of four types of innovation (product, process, marketing and organisational) on the performance of SMEs in the Sekondi-Takoradi Metropolis of Ghana.

The aim of this study was to investigate the relationship between four innovation types implemented by SMEs and organisational performance. Product innovation, process innovation, marketing innovation and organisational innovation represent the four types of 
innovation. The specific objectives were to assess the influence of: product innovation on organisational performance, process innovation on organisational performance, marketing innovation on organisational performance and organisational innovation on organisational performance. The main research question was: What is the relationship between the innovation types chosen (i.e. product, process, marketing and organisational innovation) and organisational performance?

The rest of the paper is organized into four sections. The second section discusses the relevant literature on innovation, including the research framework and research hypotheses. This is followed by the section on methodology. The third section deals with the results and discussion. And the final section is on the conclusion and recommendations.

\section{The meaning of innovation}

\section{LITERATURE REVIEW}

Innovation is closely related to the economic objective of creating differentiation (i.e., enhancing the monopolistic power of the firm in relation to its customers) (Porter, 1980; Schumpeter, 1934). According to Damanpour (1991), previous studies (Jenssen \& Nybakk, 2009; Jenssen; Åsheim, 2010 \& Tidd \& Bessant, 2011) have emphasised the importance of distinguishing between different types of innovation, because it helps in identifying the determinants of innovation.

According to the OECD (2005), an innovation is the implementation of a new or significantly improved product (good or service), or process, a new marketing method, or a new organisational method in business practices, workplace organisation or external relations. It is the process that covers product design, production system design, product introduction processes and start of production (Johanssen, 2008). "This includes the generation of opportunities, their selection and transformation into artefacts (manufactured products) and activities (services) offered to customers and the institutionalization of improvements in the new product development (NPD) activities themselves" (Ale Ebrahim, Ahmed \& Taha, 2010).

\section{Types of innovation}

The two conventional ways of differentiating between types of innovation are, firstly, the taxonomy, already suggested by Schumpeter (1934), where a differentiation is made between the types of innovation on the basis of the object of change, speaking of, for example, product, process, market and organisational innovations and, secondly, the difference between innovations on the basis of their "newness" or "radicalness", that is, based on the extent of change. According to the OECD (2005), we may have four different kinds of objects of change, i.e. product, process, market or organisational innovations. Additionally, the extent of change associated with innovation may be depicted in terms of complete newness or significant improvement. As Massa and Testa (2008) put it, academics and entrepreneurs, for example, may interpret innovation in a very dissimilar manner: while academics usually stress scientific novelty, for entrepreneurs, on the other hand, "innovation is anything that makes money."

\section{Product innovation}

Product innovation can be defined as the creation of a new product from new materials (totally new product) or the alteration of existing products to meet customer satisfaction (improved version of existing products) (Amara \& Landry, 2005). Product innovation can also be described as new developments in those activities that are undertaken to deliver the core product and make it more attractive to consumers. Product innovations are those that are capable of making use of new knowledge or technologies, and are based on new uses or combinations of existing knowledge or technologies (OECD, 2005). 


\section{Process innovation}

Process innovations are defined as new elements introduced into an organisation's production or service operation. They do not produce products or render services, but indirectly influence the introduction of products and services (Damanpour \& Gopalakrishnan, 2001). Process innovations share similarities with administrative innovations, and they affect the organisational members and relationships amongst them (Oke et al., 2007). In other words, a process innovation is the process of reengineering and improving internal operation of business process.

\section{Marketing innovation}

A marketing innovation is the implementation of a new marketing method involving significant changes in product design or packaging, product placement, product promotion or pricing. The aims of marketing innovations are to better address customer needs, open up new markets, or newly position a firm's product on the market, with the objective of increasing the firm's sales (OECD, 2005). Gunday et al. (2011) assert that marketing innovation plays a crucial role in fulfilling market needs and responding to market opportunities.

\section{Organisational innovation}

According to the OECD (2005), an organisational innovation is the implementation of a new organisational method in the firm's business practices, workplace organisation or external relations. They can either be intended to increase a firm's performance by reducing administrative costs or transaction costs, improving workplace satisfaction (and thus labour productivity), gaining access to non-tradable assets (such as non-codified external knowledge) or reducing costs of supplies.

Organisational innovations can take three main forms. Firstly, organisational innovation in business practices, which entails the application of new techniques for arranging routines and procedures for carrying out work. Secondly, organisational innovation with regard to workplace organisation, which requires the application of new methods for allocating responsibility and decision making among employees for the division of work within and between firm activities (and organisational units), as well as new concepts for the structuring of activities such as the integration of different business activities. Lastly, organisational innovation in external relations that has not been used before in the firm, and is the result of strategic decisions taken by management (OECD, 2005).

\section{Research model and hypothesis development}

This study explores the relationship between four types of innovation and organisational performance from the context of SMEs. The types of innovation comprise product innovation, process innovation, marketing innovation and organisational innovation.

\section{The relationship between product innovation and organisational performance}

With innovation, quality of products could be enhanced, which, in turn, contributes to firm performance and, ultimately, to a firm's competitive advantage (Al-Ansari et al., 2013). Bayus, Erickson and Jackson (2003) proved that product innovation had positive and significant link with organisational performance. Also, Hernandez-Espallardo and Ballester (2009) confirmed a significantly positive impact of product innovation on firm performance. Similarly, Alegre, Lapiedras and Chiva (2006) found that both product innovation dimensions (efficacy and efficiency) were strongly and positively related to firm performance. Furthermore, the introduction of a novel product was confirmed by Varis and Littunen (2010) to be positively associated with firm performance. Moreover, Walker (2005) conducted comparative research 
on the effects of product and process innovations on firm performance. They indicated that particular product improvements are positively associated with firm growth.

Besides, Tung (2012) stressed the importance of both continuous product innovation and innovation leadership to assure competitiveness, customer loyalty, and organisation survival. He opined that product innovation was directly related to an organisation's performance. Also, D' Angelo (2012) used a sample of Italian firms operating in the high tech settings within the manufacturing industry (HTSMEs). After applying a 3-year lag time approach, and running various regression models, he concluded that product innovations and the turnover derived from innovative activities positively and significantly affects the export intensity (performance) of firms.

In addition, Atalay, Anafarta and Sarvan (2013), after conducting a survey on top level managers of 113 firms operating in the automotive supplier industry, demonstrated that product innovation has significant and positive impact on firm performance. Analysing a sample of 207 firms in Australia, Oke, Jayaram and Prajogo (2013) concluded that both product innovation performance and product quality performance are found to positively affect business performance. Furthermore, the findings of Hall (2011) indicated a substantial positive relationship between product innovation activities and productivity. Likewise, Augusto, Lisboa and Yasin (2014) utilised factor and regression analyses procedures to provide insights into the relationships between organisational performance and the different facets of innovation, and concluded that specific innovation, such as product innovation, appears more significant on promoting organisational performance than organisational-wide innovation. Moreover, Ar and Baki (2011), using structural equation modelling with data collected from 270 managers of SMEs located in Turkish science and technology parks (STPs), found that product innovations have a strong and positive association with organisational performance. Finally, Mohamad and Sidek (2013) collected on a total of 284 from SMEs in the food and beverage, textiles and clothing, and wood-based sub-industries, and used hierarchical regression analysis to confirm the hypothesis that product innovation influenced firm performance significantly. Thus, the following is the first hypothesis that was developed to be tested:

H1: Product innovation positively influences organisational performance of SMEs in the Sekondi-Takoradi metropolis.

\section{The relationship between process innovation and organisational performance}

According to Pratali (2003), incremental technological (product and process) innovations help improve company competitiveness with the ultimate aim of increasing company value. Crucial to the manufacturing industry, process innovation should be emphasized by a firm as its primary distinctive competence for competitive advantage (Oke et al., 2013). More specifically, such an innovation is positively associated with firm growth (Massa \& Testa, 2008). Consistent with this argument, Varis and Littunen (2010) studied SMEs in Finland and found that process innovation is positively associated with firm performance. More so, using new technology as a proxy for process innovation, Ar and Baki (2011) reconfirmed the positive and significant influence of process innovation on firm performance.

Additionally, using a sample of 229 Portuguese manufacturing organisations, Augusto et al. (2014) utilised factor and regression analyses procedures to provide insights into the relationships between organisational performance and the different facets of innovation, and concluded that specific innovation, such as process innovation, appears more significant on promoting organisational performance than organisational-wide innovation. Madrid-Guijarro, 
Garcia, Perez, Lema and Van Auken (2013) investigated product, process and management innovation among a sample of Spanish manufacturing SMEs during the period of economic downturn and a period of economic growth. They concluded that process innovation was positively associated with firm performance during the economic expansion and recession years.

Similarly, Varis and Littunen (2010) suggested that the introduction of novel process innovations is positively associated with firms' growth. Equally, Valmohammadi (2012) investigated the innovation management practices in Iranian organisations and concluded that both appropriate innovation inputs and effective innovation processes are positively related to business performance. Likewise, Mohamad and Sidek (2013) used hierarchical regression analysis to examine the relationship between innovation and performance of 284 Malaysian SMEs in the food and beverage, textiles and clothing as well as wood-based sub-industries to confirm the hypothesis that process innovation influenced firm performance significantly.

Correspondingly, Atalay et al. (2013) demonstrated that process innovation has significant and positive impact on firm performance. In the same way, Ar and Baki (2011) used structural equation modelling with data collected from 270 managers of SMEs located in Turkish science and technology parks and found that process innovations have a strong and positive association with organisational performance. Hence, the following is the second hypothesis that was developed to be tested:

H2: Process innovation positively influences organisational performance of SMEs in the Sekondi-Takoradi metropolis.

\section{The relationship between marketing innovation and organisational performance}

Johne and Davies (2000) ensured that marketing innovations increase sales by increasing product consumption to yield additional profit to firms. They further explained that incremental market innovation is about new ways of reading and serving current markets, which ensures firms to provide appropriate offers that yields greater avenues (Johne \& Davies, 2000). Sandvik (2003) discovered that market innovation has a positive effect on sales growth of a firm, whilst Varis and Littunen (2010), using an estimated model, confirmed a highly significant relationship between a market-related innovative activity and firm performance.

Similarly, Otero-Neira, Lindman and Fernandez (2009) found strong evidence that market innovation positively influenced business performance. Equally, Atalay et al. (2013) investigated top level managers of 113 firms operating in the automotive supplier industry in Turkey and found no evidence of a significant and positive relationship between marketing innovation and firm performance. Consequently, the third hypothesis that was developed to be tested is:

H3: Marketing innovation positively influences organisational performance of SMEs in the Sekondi-Takoradi metropolis.

\section{The relationship between organisational innovation and organisational performance}

Despite the weak link they found, Lin and Chen (2007) associated innovations with increased firm sales; and they argued that organisational innovations, rather than technological innovations, appeared to be the most vital factor for total sales. Dadfar, Dahlgaard, Brege, and Alamirhoor (2013) examined the relationship between organisational innovation capability and performance in pharmaceutical small and medium enterprises in Iran. They concluded 
that a positive relationship between innovation capabilities and performance existed. They attributed this relationship to the effective innovation management and commitment across the organisation. Using 280 senior, executive and administrative level managers from 106 Iranian manufacturing firms through structural equation modelling, Noruzy, Dalfard, Azhdari, Nazari-Shirkouhi and Rezazadeh (2013) found that organisational learning and organisational innovation directly influenced organisational performance.

Additionally, Camisón and Villar-López (2014) used empirical evidence from a survey of 144 Spanish industrial firms and a system of structural equations to confirm that organisational innovation favours the development of technological innovation capabilities, and that both organisational innovation and technological capabilities for products and processes can lead to superior firm performance. This notwithstanding, Atalay et al. (2013), in their study of top level managers of 113 firms operating in the automotive supplier industry, found no evidence of a significant and positive relationship between organisational innovation and organisational performance. Therefore, the fourth hypothesis that was developed to be tested is:

H4: Organisational innovation positively influences organisational performance of SMEs in the Sekondi-Takoradi metropolis.

\section{Conceptual framework of innovation and organisational performance}

For the purpose of this study, the definition of innovation by the OECD (2005) was adopted. Hence, the conceptual framework for the study was based on how the OECD (2005) elucidated the construct of innovation, and defined an innovative firm as one that has implemented an innovation during the period under review. The conceptual framework for this study was, therefore, based on the works of Gunday et al. (2011), as illustrated in Figure 1.

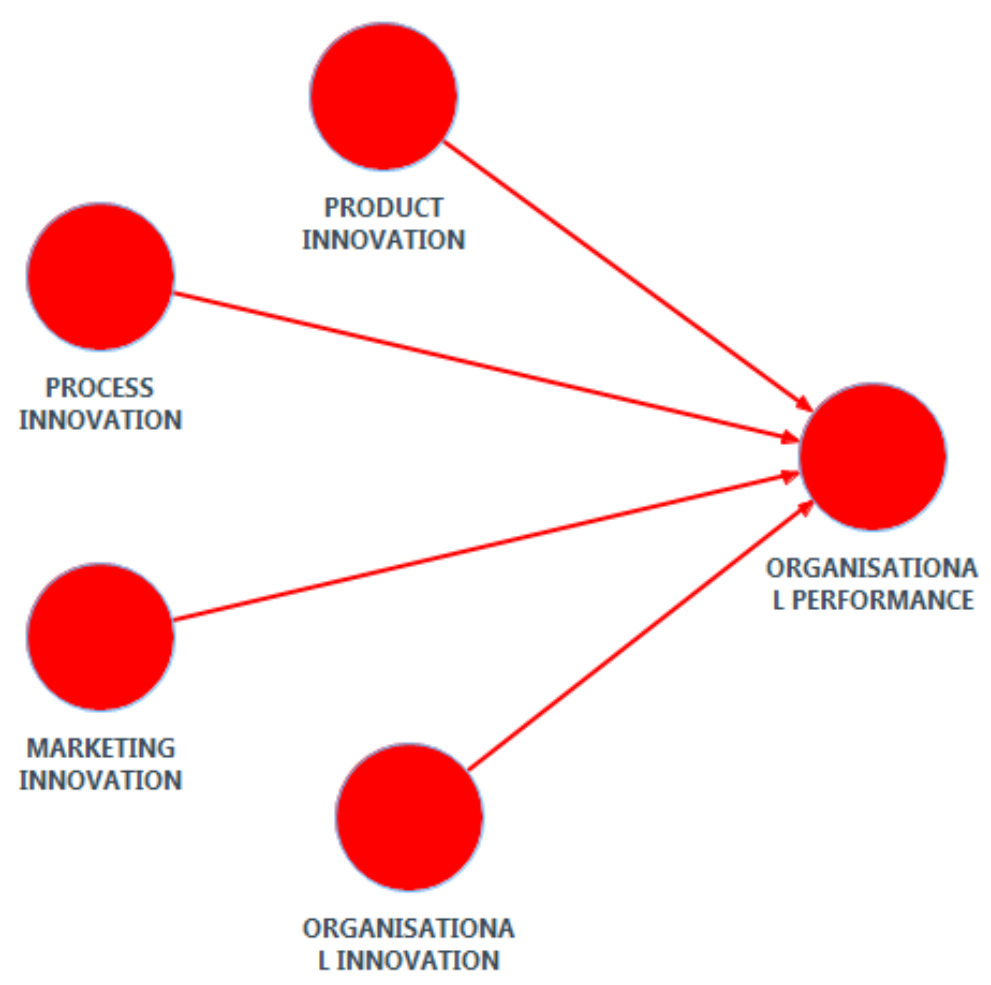

Figure 1: Conceptual framework

Source: Researchers' construct, 2014. 
The model for the study was structured to reflect the relationships between innovation and performance. Product innovation (APDINV) positively influences organisational performance, process innovation (BPCINV) positively influences organisational performance, marketing innovation (CMKINV) positively influences organisational performance and organisational innovation (DOGINV) positively influences organisational performance.

\section{Research approach and study design}

\section{METHODOLOGY}

According to Yates (2003), there are two main approaches to conducting research, namely the quantitative research and qualitative research. The quantitative approach was adopted for this research, not only because of the nature of the study objective, research questions and hypotheses, but also because of the advantages it offers over the qualitative approach. The main advantage of the quantitative research approach over the qualitative research approach is that it is a scientific, fast and easier alternative, which enables statistical analyses of data, generalisation of findings, drawing of logical conclusions based on numerical values and comparability of studies (Sekeran, 2010).

Specifically, the descriptive-inferential survey design was adopted for this study. Surveys are a type of research design involving the collection and analysis of large amounts of quantitative data from a sizeable population using descriptive and inferential statistics (Tabachnick \& Fidell, 2007). According to Saunders, Saunders, Lewis and Thornhill (2011), the survey is a popular as well as an authoritative strategy that gives researchers more control over the research process and is comparatively easy to explain and understand. It is popular, because it allows the collection of a large amount of data from a suitable population in a highly economical way.

\section{Population, sample and sampling procedure}

Sampling plan concerns the development of specific procedures and operational methods in selecting the sample (Zikmund, 2012) that can be followed to avoid potential errors (Uma, 2003). In this study, the target population consisted of all the manufacturing SMEs in the Sekondi-Takoradi metropolis. Out of the total of 1800 manufacturing SMEs found in the sampling frame, whose names were obtained from National Board for Small Scale Industries (NBSSI), a representative sample of 322 was drawn for the study, using Krejcie and Morgan's (1970) table. Simple random sampling method, specifically lottery method, was adopted in selecting these manufacturing SMEs from the population. This technique was chosen because it provides an opportunity for each of the manufacturing SMEs to have an equal chance of being selected. Thus, 322 survey questionnaires were distributed to the respondents of SMEs with the expectation of obtaining a high response rate (Sekeran, 2010).

\section{Measurement of variables and the model}

The five types of innovation used in this research were developed after a careful review of existing literature and expert opinions (e.g. Gundey et al., 2011; Al-Ansari et al, 2013) A total of 20 items were used to measure the five types of innovation. Six (6) items were used to measure organisational performance. These items were adapted from past researchers' approaches (Oke et al., 2007; Gundey et al., 2011; Avci et al., 2011; Al-Ansari et al., 2013). A 5-point rating scale was used to measure all the items used in this research. The following section explains the specific data analysis methodology that was used in this study. 


\section{Reliability and validity testing}

As suggested by Hair et al. (2006), the coefficient alpha of 0.60 or above mean suggests that the items are performing well in capturing a specific latent variable. Items were all found to display item-to-total correlations greater than the criterion of 0.50 . The overall results of latent variables composite coefficient alpha fell within the acceptable ranges that were from 0.821 to 0.949 (Appendix A). The final version of the questionnaire comprised five pages, four sections, and 34 questions.

\section{Data collection and analysis procedure}

The cross sectional survey design was used in collecting data for this study. The crosssectional design time dimension was consistent with the descriptive research approach as well as time and cost constraints for this research study. A top-down approach was selected as the most appropriate method for executing the questionnaire and the questionnaires were sent to managers or owner managers of the selected SMEs. This was due to the fact that the nature of information and data required can best be provided by the managers or owners-managers of firms under research (Li, Zhou \& Si, 2010; Martinez-Roman, Gamer \& Tamayo, 2011). The selfadministrated survey was used with the advantages of: administrative speed, response rate, questions and items clarity, motivation, anonymity, and sample and quality control (Creswell, 2013). Even though self-administered surveys come with some disadvantages, they were minimized, where possible, and did not outweigh the benefits provided by high response rates in a short period of time. The rationale behind this selection was to be able to offer benefits, such as reduction of interviewer bias, accommodation of long survey, and to obtain a large sample.

By virtue of the nature of the research objective, structural equation modelling techniques were used for the analyses. According to Hair, Sarstedt, Hopkins and Kuppelwieser (2014), the use of these techniques required that certain underlying assumptions were met before the results could be relied upon. These assumptions are related to sample size, multicollinearity, indicator reliability, construct reliability, convergent validity, discriminant validity as well as outer model significance. Prior tests were, therefore, carried out to ensure that these assumptions were met.

\section{Sample size}

For sample size, Hair et al.'s (2011) formula for calculating the minimum sample size requirement for use in PLS-SEM was applied. The minimum sample size should be equal to the larger of the following: (1) ten times the largest number of formative indicators used to measure one construct or (2) ten times the largest number of structural paths directed at a particular latent construct in the structural model. For this study, there are no formative indicators, but the largest number of structural paths directed at a particular latent construct in the structural model is 4 . Hence, the minimum sample size will be $4 * 10=40$. Cohen's (1992) table (Appendix B) for determining sample size in PLS-SEM was used in determining the minimum sample size. With the maximum number of arrows pointing at a construct of 4 , a significant level of 0.05 , minimum R 2 of 0.10 and a statistical power of $80 \%$, the minimum sample size is 137 (Appendix B). Since $243>137$, the minimum sample size requirement was duly met.

\section{Multicolinearity}

Pallant (2007) suggested that tolerance values of below .10 and variable inflation factor (VIF) values of above 10 indicated multicollinearity among independent variables, thereby hindering the development of good PLS-SEM models. The tolerance values ranging from (.413) to (.799) and V.I.F values also ranging from (1.252) to (2.423), obtained from this analysis, indicated the 
absence of multicollinearity between the exogenous variables. Appendix C displays the tolerance vales as well as VIF values for the predictor variables.

\section{Indicator reliability}

Indicator reliability specifies which part of an indicator's variance can be explained by the underlying latent variable. A common threshold criterion is that more than $50 \%$ of an indicator's variance should be explained by the latent construct. With respect to the squared loadings, values $\geq 0.7$ are preferred, whilst values $\geq 0.4$ are acceptable (Hulland, 1999). The indicators used in this model can be said to be reliable because all the squared loadings ranging from 0.4158 to 0.8359 are within the acceptable threshold of 0.4 or higher (Hulland, 1999).

\section{Construct reliability}

Although small indicator reliabilities may point to a given indicator's inadequate measurement of a construct, it is usually more important that all the construct's indicators jointly measure the construct adequately (Bagozzi \& Yi, 1988). The preferred Composite reliability value is any value that is higher or equal to 0.70 , even though values higher or equal to 0.6 are acceptable when the research is exploratory (Bagozzi \& Yi, 1988). In this study, internal consistency reliability was tested by extracting the Cronbach's alpha and composite reliability coefficient (Appendix D). All latent variables have the appropriate levels of Cronbach's alpha ranging from 0.808 to 0.914 and composite reliability values ranging from 0.861 to 0.936 (Appendix D). The model can, therefore, be said to have internal consistency reliability.

\section{Convergent validity}

According to Gotz et al. (2010), a common measure to examine convergent validity in SEM models is the average variance extracted (AVE). Support is provided for convergent validity when each construct's average variance extracted (AVE) is 0.50 or higher (Bagozzi \& Yi, 1988; Hair et al., 2011). In this study, convergent validity was tested by examining the AVEs of all the variables (see Appendix D). It was illustrated that the validity of the measurement scale was convergent, because all latent variable had AVEs of 0.5 or higher, ie. from 0.509 to 0.746 ( Appendix D).

\section{Discrininant validity}

It is also recommended to test whether a study has discriminant validity (Hair et al., 2011). To ensure discriminant validity for each latent construct, the square roots of the average variance extracted (AVEs) should be larger than any of the correlations involving that latent construct (Hair et al., 2011). One method for assessing the existence of discriminant validity is the Fornell and Larcker's (1981) criterion. This method suggests that the square root of AVE of each latent variable can be used to establish discriminant validity, if this value is larger than other correlation values among the latent variables.

The second option for verifying discriminant validity is examining the cross loadings of the indicators. It is recommended that the measurement indicators' loadings on their assigned constructs should be in an order of magnitude larger than their loadings on the other constructs (Hair et al., 2012). It can be confirmed that (Appendix D) the model demonstrates an appropriate level of discriminant validity, because the individual square roots of the AVEs for each latent variable is higher than any of the correlations shown below or above them. Additionally, the loadings of each indicator on its construct are higher than the cross loadings on other constructs (Appendix E). Thus, it can be concluded that the latent variables have discriminant validity. 


\section{Outer model significance}

Finally, Wong (2013) recommended that all outer model loadings should be significant at the chosen alpha level. As presented in Appendix G, all T-statistics of the outer model loadings are larger than 1.96, meaning that all outer model loadings are significant at the chosen alpha level of .05.

\section{Hypothesis testing}

\section{RESULTS AND DISCUSSION}

This study sought to test four hypotheses. These hypotheses are concerned with determining the influence that product innovation, process innovation, marketing innovation and organisational innovation have on organisational performance of SMEs operating within the Sekondi-Takoradi metropolis. The first hypothesis was formulated to determine whether there is a relationship between product innovation and organisational performance. The formulated hypothesis was:

\section{H1: Product innovation positively influences organisational performance.}

The analysis of the data collected proved that product innovation (APDINV) had a non significant positive effect on organisational performance (OGPERF) $(\beta=0.109, p>0.05$; Appendix H). The beta coefficient was in the right direction, as hypothesized; hence, the hypothesis that "Product innovation positively influences organisational performance" was supported. This implies that an increase in product innovation would result in an increase in the performance of SMEs. Thus, SMEs that are able to record high levels of product innovation activities would perform well on both financial and non-financial performance indicators. The result is consistent with some of the findings in earlier studies, which reported significant positive relationship between product innovation and organisational performance. For example, Augusto et al. (2014) found a positive relationship between product innovation and organisational performance in their study of innovation and business performance in SMEs. Other studies also supported a positive relationship between product innovation and organisational performance (Hall, 2011; D' Angelo, 2012; Atalay et al., 2013).

The second hypothesis was formulated to determine whether there exists a positive influence of process innovation on organisational performance. The formulated hypothesis was:

\section{H2: Process innovation positively influences organisational performance.}

The analysis of the data collected showed that process innovation had significant positive effect on organisational performance (OGPERF) $(\beta=0.255, \mathrm{p}<0.05$; Appendix $H)$. The beta coefficient was in the right direction, as hypothesized; hence, the hypothesis that "Process innovation positively influences organisational performance" was supported. This suggests that an increase in process innovation would result in an increase in the performance of SMEs. Thus, SMEs that have high levels of process innovation activities would perform well on both financial and non-financial performance indicators. The result is consistent with some of the findings of Ar and Baki (2011), who opined that process innovations have a strong and positive association with organisational performance as well as Mohamad and Sidek's (2013), who also confirmed the hypothesis that process innovation influenced firm performance significantly.

The third hypothesis was formulated to determine whether there exists a positive influence of marketing innovation on organisational performance. The formulated hypothesis was:

H3: Marketing innovation positively influences organisational performance. 
The analysis of the data collected showed that marketing innovation (CMKINV) had significant positive influence on organisational performance (OGPERF) ( $\beta=0.297, p<0.05$; Appendix H). The beta coefficient was in the right direction, as hypothesized; hence, the hypothesis that "Marketing innovation positively influences organisational performance" was supported. This implies that an increase in process innovation would result in an increase in the performance of SMEs. Thus, SMEs that have levels of process innovation activities would perform well on both financial and non-financial performance indicators. The result is consistent with some of the findings in earlier studies, which reported significant positive relationship between process innovation and organisational performance. For instance, Varis and Littunen (2010), using an estimated model, confirmed a highly significant relationship between a market-related innovative activity and firm performance. Also, Gunday et al (2011), in their study of innovation, organisational learning and performance, established a positive relationship between process innovation and organisational performance.

The fourth hypothesis was formulated to determine whether there exists a positive influence of organisational innovation on organisational performance. The formulated hypothesis was:

\section{H4: Organisational innovation positively influences organisational performance.}

Analysis of the data collected showed that organisational innovation (DOGINV) had significant positive influence on organisational performance (OGPERF) ( $\beta=0.196, p<0.05$; Appendix $H$ ). The beta coefficient was in the right direction, as hypothesized; hence, the hypothesis that "Organisational innovation positively influences organisational performance" was supported. This suggests that an increase in process innovation would result in an increase in the performance of SMEs. Thus, SMEs that have levels of process innovation activities would perform well on both financial and non-financial performance indicators. The result is consistent with some of the findings in earlier studies, which reported significant positive relationship between process innovation and organisational performance (Dadfar et al., 2013; Noruzy et al., 2013; Camisón \& Villar-López, 2014).

\section{Explanation of target endogenous variable variance}

The model further suggests that the endogenous latent variable, organisational performance (EOGPEF), has a coefficient of determination, R2, of 0.514 . The deduction that can be made is that the four latent variables of product innovation, process innovation, marketing innovation and organisational innovation (APDINV, BPCINV, CMKINV and DOGINV) moderately explain $51.4 \%$ of the difference in organisational performance (EOGPEF).

\section{Predictive Relevance}

The Q2 is used to assess the predictive relevance of the inner model. It is claimed that a $\mathrm{Q}^{2}$ larger than 0 means that the model has predictive relevance, whereas a $Q^{2}$ lower than 0 implies that the model is deficient in predictive relevance (Rigdon, 2010; Hiar et al., 2011; Roldán \& Sanchez-Franco, 2012; Sarstedt et al., 2014). Appendix I demonstrates that the Qsquared coefficients for the predictive relevance associated with each latent variable block in the model, through the dependent latent variables, are all larger than zero, which indicates that the model has predictive relevance.

\section{Effect sizes ( $f 2$ ) of exogenous variables}

The effect size for each path model is determined by calculating Cohen's f2. The f2 is computed by noting the change in $\mathrm{R} 2$ when a specific construct is eliminated from the model. Based on the $f 2$ value, the effect size of the omitted construct for a particular endogenous construct can 
be determined and values of $0.02,0.15$, and 0.35 can be viewed as indicating that an independent latent variable has a low, moderate or large effect respectively at the structural level (Roldán \& Sanchez-Franco, 2012). The effect size is to be calculated using the formula: f2 $=(\mathrm{R} 2$ included $-\mathrm{R} 2$ excluded $) /(1-\mathrm{R} 2$ included $)$. Appendix $\mathrm{J}$ indicates the effect sizes of the various structural paths in the model, where APDINV/ EOGPEF is small, BPCINV / EOGPEF is small, CMKINV / EOGPEF is small and DOGINV / EOGPET is also small.

\section{CONCLUSION AND RECOMMENDATIONS}

The influence of product innovation, process innovation, marketing innovation and organisational innovation on organisational performance was assessed, and the major issues that emerged from the findings show that: Product innovation positively influenced organisational performance levels of the SMEs $(\mathrm{R} 2=.015 ; \mathrm{p}>0.05)$. Process innovation positively influenced organisational performance levels of the SMEs $(R 2=.008 ; \mathrm{p}<0.05)$. Marketing innovation positively influenced organisational performance levels of the SMEs (R2 $=.033 ; \mathrm{p}<0.05)$. Organisational innovation positively influenced organisational performance levels of the SMEs (R2 $=.030 ; \mathrm{p}<0.05)$. Marketing innovation $(=3.837)$, and organisational innovation ( $=3.819$ ), the highest types of innovation, had the most influence on organisational performance. The composite effect of product innovation, process innovation, marketing innovation and organisational innovation on organisational performance was also assessed, and the findings indicate that product innovation, process innovation, marketing innovation and organisational innovation collectively predicted the level of performance of the SMEs significantly ( $22=.514 ; \mathrm{p}<0.05)$, where innovation accounted for $51.4 \%$ of the variation in organisational performance.

It is concluded from the study that all the types of innovation had positive impact on organisational performance. Also, except for product innovation, the effects were significant. Of all the types of innovation, marketing innovation had the most impact on organisational performance with product innovation acting as the least contributor to organisational performance. The influence of marketing innovation on organisational performance is largely enhanced by the level of organisational innovation implemented by the organisation. Also, the level of innovation implemented by the organisation significantly influences its performance. The results further show that innovation accounts for more than fifty percent of the variation in organisational performance. In summary, all the four types of innovation positively influence organisational performance. Innovation-oriented managers and/or owner managers should ensure that there is adequate investment in product, process, marketing as well as organisational innovation activities, thereby avoiding the risk of not being able to achieve their strategic objectives.

Based on the findings and conclusions presented, it is recommended that owners/managers of SMEs should develop newness for current products, leading to improved ease of use for customers as well as improved customer satisfaction. This can be achieved by determining as well as eliminating non-value adding activities in delivery related processes of their products and also renewing the design of current and/or new products through changes in areas such as appearance, packaging, shape and volume without changing their basic technical and functional features. Also, owner managers of SMEs should not only pay attention to activities geared towards renewing the routines, procedures and processes employed to execute firm activities in an innovative manner, but also invest in marketing innovation activities, as it has the largest influence on organisational performance. Furthermore, with regard to policy direction, results from the study imply that policy makers need to provide some form of education that would highlight the importance of innovation in SMEs and how such innovation 
translates into increased performance. The government should also provide an enabling environment that would support the execution of this business strategy.

The confinement of the population to SMEs operating in the Sekondi-Takoradi metropolis renders the findings, conclusions and recommendations applicable mainly to this group of SMEs. Secondly, the reliance on key decision makers as the sole respondents raises questions bordering on possible bias, particularly with the assessment of firm performance. Finally, the use of close-ended as well as rating scale type questions restricts the amount of information obtainable from respondents, particularly on the main variables of the study.

Future studies should be carried out to examine the relationships among the four different types of innovation. This will provide in-depth clarification with regard to how each type of innovation relates to one another as well as how that relationship enhances performance. Also, a replication of this study on a longitudinal basis will reveal trends in the behaviour of the different types of innovation and enhance the worth of recommendations made to the firms under study. Finally, a study involving only manufacturing firms or only service firms will provide a more detailed picture of how innovation relates to organisational performance growth.

\section{References}

Al-Ansari, Y., Pervan, S., \& Xu, J. (2013). Innovation and business performance of SMEs: The case of Dubai. Education, Business and Society: Contemporary Middle Eastern Issues, 6(3/4), 162-180.

Ale Ebrahim, N., Ahmed, S., \& Taha, Z. (2010). Critical factors for new product developments in SMEs virtual team. African Journal of Business Management, 4(11), 2247-2257.

Alegre, J., Lapiedra, R., \& Chiva, R. (2006). A measurement scale for product innovation performance. European Journal of Innovation Management, 9(4), 333-346.

Amara, N., \& Landry, R. (2005). Sources of information as determinants of novelty of innovation in manufacturing firms: Evidence from the 1999 statistics Canada innovation survey. Technovation, 25(3), 245-259.

Ar, I. M., \& Baki, B. (2011). Antecedents and performance impacts of product versus process innovation: Empirical evidence from SMEs located in Turkish science and technology parks. European Journal of Innovation Management, 14(2), 172-206.

Atalay, M., Anafarta, N., \& Sarvan, F. (2013). The relationship between innovation and firm performance: An empirical evidence from Turkish automotive supplier industry. Procedia-Social and Behavioral Sciences, 75, 226-235.

Augusto, M. G., Lisboa, J. V., \& Yasin, M. M. (2014). Organisational performance and innovation in the context of a total quality management philosophy: An empirical investigation. Total Quality Management \& Business Excellence (aheadof-print), 1-15.

Avci, U., Madanoglu, M., \& Okumus, F. (2011). Strategic orientation and performance of tourism firms: Evidence from a developing country. Tourism management, 32(1), 147-157.

Bagozzi, R. P., \& Yi, Y. (1988). On the evaluation of structural equation models. Journal of the Academy of Marketing Science, 16(1), 74-94.

Bayus, B. L., Erickson, G., \& Jacobson, R. (2003). The financial rewards of new product introductions in the personal computer industry. Management Science, 49(2), 197-210.

Cagliano, R., \& Spina, G. (2002). A comparison of practice-performance models between small manufacturers and subcontractors. International Journal of Operations \& Production Management, 22(12), 1367-1388.

Camisón, C., \& Villar-López, A. (2014). Organisational innovation as an enabler of technological innovation capabilities and firm performance. Journal of Business Research, 67(1), 2891-2902.

Carayannis, E. G., \& Gonzalez, E. (2003). Creativity and innovation competitiveness? When, how, and why. The international handbook on innovation, 587-606. 
Cosh, A., \& Hughes, A. (2000). British enterprise in transition: Growth, innovation and public policy in the small and medium sized enterprise sector 1994-1999. Cambridge: ESRC Centre for Business Research.

D'Angelo, A. (2012). Innovation and export performance: A study of Italian high-tech SMEs. Journal of Management \& Governance, 16(3), 393-423.

Dadfar, H., Dahlgaard, J. J., Brege, S., \& Alamirhoor, A. (2013). Linkage between organisational innovation capability, product platform development and performance: The case of pharmaceutical small and medium enterprises in Iran. Total Quality Management \& Business Excellence, 24(7-8), 819-834.

Damanpour, F. (1991). Organisational innovation: A meta-analysis of effects of determinants and moderators. Academy of management journal, 34(3), 555-590.

Damanpour, F., \& Gopalakrishnan, S. (2001). The dynamics of the adoption of product and process innovations in organizations. Journal of management studies, 38(1), 45-65.

De Jong, J. P., \& Vermeulen, P. A. (2006). Determinants of product innovation in Small Firms: A comparison across industries. International Small Business Journal, 24(6), 587-609.

Fornell, C., \& Larcker, D. F. (1981). Evaluating structural equation models with unobservable variables and measurement error. Journal of Marketing Research (JMR), 18(1).

Gopalakrishnan, S., \& Damanpour, F. (1997). A review of innovation research in economics, sociology and technology management. Omega, 25(1), 15-28.

Götz, O., Liehr-Gobbers, K., \& Krafft, M. (2010). Evaluation of structural equation models using the partial least squares (PLS) approach. In V. Esposito Vinzi, W.W. Chin, J. Henseler, \& H. Wang (Ed.), Handbook of partial least squares: Concepts, methods and applications (pp. 691-711). Berlin: Springer.

Gunday, G., Ulusoy, G., Kilic, K., \& Alpkan, L. (2011). Effects of innovation types on firm performance. International Journal of Production Economics, 133(2), 662-676.

Hair, J. F., Ringle, C. M., \& Sarstedt, M. (2011). PLS-SEM: Indeed a silver bullet. The Journal of Marketing Theory and Practice, 19(2), 139-152.

Hair, J. F., Sarstedt, M., Hopkins, L., \& Kuppelwieser, V. G. (2014). Partial least squares structural equation modeling (PLS-SEM): An emerging tool in business research. European Business Review, 26(2), 106-121.

Hair, J. F., Sarstedt, M., Ringle, C. M., \& Mena, J. A. (2012). An assessment of the use of partial least squares structural equation modelling in marketing research. Journal of the Academy of Marketing Science, 40(3), 414-433.

Hair, J., Black, W., Babin, B., Anderson, R., \& Tatham, R. (2006). Multivariate data analysis (6thed.). New Jersey: Pearson Prentice Hall.

Hall, B. H. (2011). Innovation and productivity. National Bureau of Economic Research. 17178. doi: 10.3386/w17178

Hernández-Espallardo, M., \& Delgado-Ballester, E. (2009). Product innovation in small manufacturers, market orientation and the industry's five competitive forces: Empirical evidence from Spain. European Journal of Innovation Management, 12(4), 470-491.

Hulland, J. (1999). Use of partial least squares (PLS) in strategic management research: a review of four recent studies. Strategic Management Journal, 20(2), 195-204.

Jenssen, J. I., \& Aasheim, K. (2010). Organisational innovation promoters and performance effects in small, knowledgeintensive firms. The International Journal of Entrepreneurship and Innovation, 11(1), 19-27.

Jenssen, J. I., \& Nybakk, E. (2009). Inter-organisational innovation promoters in small, knowledge-intensive firms. International Journal of Innovation Management, 13(03), 441-466.

Johansson, G. (2008). Product innovation for sustainability: on product properties for efficient disassembly. International Journal of Sustainable Engineering, 1(1), 32-41.

Johne, A., \& Davies, R. (2000). Innovation in medium-sized insurance companies: How marketing adds value. International Journal of Bank Marketing, 18(1), 6-14. 
Mensah, F. B., \& Acquah, I. S. K. (2015). The Effect of Innovation Types on the Performance of Small and Medium Sized enterprises in the SekondiTakoradi Metropolis. Archives of Business Research, 3(3), 77-98.

Li, Y., Zhou, N., \& Si, Y. (2010). Exploratory innovation, exploitative innovation, and performance: influence of business strategies and environment. Nankai Business Review International, 1(3), 297-316.

Lin, C. Y.-Y., \& Chen, M. Y.-C. (2007). Does innovation lead to performance? An empirical study of SMEs in Taiwan. Management Research News, 30(2), 115-132.

Madrid-Guijarro, A., García-Pérez-de-Lema, D., \& Van Auken, H. (2013). An investigation of Spanish SME innovation during different economic conditions. Journal of Small Business Management, 51(4), 578-601.

Massa, S., \& Testa, S. (2008). Innovation and SMEs: Misaligned perspectives and goals among entrepreneurs, academics, and policy makers. Technovation, 28(7), 393-407.

Mohamad, M. R., \& Sidek, S. (2013). Innovation and firm performance: Evidence from Malaysian small and medium enterprises. In The 20th International Business Information Management Conference (IBIMA). International Business Information Management Association (pp. 794-809). ISBN 978098214899.

Noruzy, A., Dalfard, V. M., Azhdari, B., Nazari-Shirkouhi, S., \& Rezazadeh, A. (2013). Relations between transformational leadership, organisational learning, knowledge management, organisational innovation, and organisational performance: an empirical investigation of manufacturing firms. The International Journal of Advanced Manufacturing Technology, 64(5-8), 1073-1085.

OECD, (2005). Oslo manual: Guidelines for Collecting and Interpreting Innovation Data (3rd ed.). Paris: Organisation for Economic Co-Operation and Development (in joint publication with Eurostat).

Oke, A., Burke, G., \& Myers, A. (2007). Innovation types and performance in growing UK SMEs. International Journal of Operations \& Production Management, 27(7), 735-753.

Oke, A., Prajogo, D. I., \& Jayaram, J. (2013). Strengthening the innovation chain: The role of internal innovation climate and strategic relationships with supply chain partners. Journal of Supply Chain Management, 49(4), 43-58.

Otero-Neira, C., Lindman, M. T., \& Fernández, M. J. (2009). Innovation and performance in SME furniture industries: An international comparative case study. Marketing Intelligence \& Planning, 27(2), 216-232.

Pallant, J. (2007). A step-by-step guide to data analysis using SPSS version 15. Maidenhead: Open University.

Porter, M. E. (1980). Competitive strategy: Techniques for analyzing industries and competitors. New York: Free Press.

Pratali, P. (2003). Strategic management of technological innovations in the small to medium enterprise. European Journal of Innovation Management, 6(1), 18-31.

Rigdon, E. E., Ringle, C. M., \& Sarstedt, M. (2010). Structural modeling of heterogeneous data with partial least squares. Review of marketing research, 7, 255-296.

Roldán, J. L., \& Sánchez-Franco, M. J. (2012). Variance-based structural equation modeling: guidelines for using partial least squares in information systems research. Research methodologies, innovations and philosophies in software systems engineering and information systems, 193-221.

Sandvik, I. L., \& Sandvik, K. (2003). The impact of market orientation on product innovativeness and business performance. International Journal of Research in Marketing, 20(4), 355-376.

Sanz-Valle, R., Naranjo-Valencia, J. C., Jiménez-Jiménez, D., \& Perez-Caballero, L. (2011). Linking organisational learning with technical innovation and organisational culture. Journal of Knowledge Management, 15(6), 997-1015.

Sarstedt, M., Ringle, C. M., Henseler, J., \& Hair, J. F. (2014). On the emancipation of PLS-SEM: A commentary on Rigdon (2012). Long range planning, 47(3), 154-160.

Saunders, M. N., Saunders, M., Lewis, P., \& Thornhill, A. (2011). Research methods for business students. Delhi: Pearson Education.

Schumpeter, J. A. (1934). The theory of economic development: An inquiry into profits, capital, credit, interest, and the business cycle. New York: Transaction Publishers.

Sekaran, U., \& Bougie, R. (2010). Research methods for business: A skill building approach. London: Wiley. 
Sirmon, D. G., Hitt, M. A., Ireland, R. D., \& Gilbert, B. A. (2011). Resource orchestration to create competitive advantage breadth, depth, and life cycle effects. Journal of management, 37(5), 1390-1412.

Tabachnick, B., \& Fidell, L. (2007). Multivariate analysis of variance and covariance: Using multivariate statistics. Boston: Allyn \& Bacon.

Ti6v 7uu, / '.'33; dd, J., \& Bessant, J. (2011). Managing innovation: integrating technological, \B 8 V market and Organisational change. New Jersey: John Wiley \& Sons.

Tung, J. (2012). A study of product innovation on firm performance. International Journal of Organisational Innovation, 4(3).

Uma, S. (2003). Research methods for business. New York: Hermitage Publishing Service.

Valmohammadi, C. (2012). Investigating innovation management practices in Iranian organizations.

Innovation, Management, Policy \& Practice, 14(2), 247-255.

Vanhaverbeke, W., \& Peeters, N. (2005). Embracing innovation as strategy: Corporate venturing, competence building and corporate strategy making. Creativity and Innovation Management, 14(3), 246-257.

Varis, M., \& Littunen, H. (2010). Types of innovation, sources of information and performance in entrepreneurial SMEs. European Journal of Innovation Management, 13(2), 128-154.

Wong, K. K.-K. (2013). Partial least squares structural equation modelling (PLS-SEM) techniques using SmartPLS. Marketing Bulletin, 24.

Yates, S. (2003). Doing social science research. London: Sage.

Zikmund, W., Babin, B., Carr, J., \& Griffin, M. (2012). Business research methods. London: Cengage Lzearning.

\section{APPENDIXES}

APPENDIX A

Computed reliability coefficients for pilot study

\begin{tabular}{lllll}
\hline Variable & $\begin{array}{l}\text { No. of } \\
\text { items }\end{array}$ & $\begin{array}{l}\text { Sample } \\
\text { Size }\end{array}$ & $\begin{array}{l}\text { Cronbach's } \\
\text { Alpha }\end{array}$ & $\begin{array}{l}\text { Composite } \\
\text { Reliability }\end{array}$ \\
\hline Product Innovation & 5 & 21 & 0.879 & 0.913 \\
Process Innovation & 5 & 21 & 0.823 & 0.833 \\
Marketing Innovation & 5 & 21 & 0.802 & 0.821 \\
Organisational Innovation & 5 & 21 & 0.759 & 0.949 \\
Organisational Performance & 6 & 21 & 0.935 & 0.840 \\
\hline
\end{tabular}

Source: Field work, 2014 
Cohen's table for determining sample size in PLS-SEM

\begin{tabular}{|c|c|c|c|c|c|c|c|c|c|c|c|c|}
\hline Sample size recommenda & tion in & PLS- & EM & & & & & & & & & \\
\hline \multirow{4}{*}{$\begin{array}{l}\text { Maximum number of } \\
\text { arrows pointing at a } \\
\text { construct }\end{array}$} & \multicolumn{12}{|c|}{ Significant level } \\
\hline & \multicolumn{4}{|l|}{$1 \%$} & \multicolumn{4}{|l|}{$5 \%$} & \multicolumn{4}{|c|}{$10 \%$} \\
\hline & \multicolumn{4}{|c|}{ Minimum $\mathrm{R}^{2}$} & \multicolumn{4}{|c|}{ Minimum $\mathrm{R}^{2}$} & \multicolumn{4}{|c|}{ Minimum $\mathrm{R}^{2}$} \\
\hline & 0.1 & 0.2 & 0.5 & 0.75 & 0.1 & 0.2 & 0.5 & 0.75 & 0.1 & 0.2 & 0.5 & 0.75 \\
\hline 2 & 158 & 75 & 47 & 38 & 110 & 52 & 33 & 26 & 88 & 41 & 26 & 21 \\
\hline 3 & 176 & 84 & 53 & 42 & 124 & 59 & 38 & 30 & 100 & 48 & 30 & 25 \\
\hline 4 & 191 & 91 & 58 & 46 & 137 & 65 & 42 & 33 & 111 & 53 & 34 & 27 \\
\hline 5 & 205 & 98 & 62 & 50 & 147 & 70 & 45 & 36 & 120 & 58 & 37 & 30 \\
\hline 6 & 217 & 103 & 66 & 53 & 157 & 75 & 48 & 39 & 128 & 62 & 40 & 32 \\
\hline 7 & 228 & 109 & 69 & 56 & 166 & 80 & 51 & 41 & 136 & 66 & 42 & 35 \\
\hline 8 & 238 & 114 & 73 & 59 & 174 & 84 & 54 & 44 & 143 & 69 & 45 & 37 \\
\hline 9 & 247 & 119 & 76 & 62 & 181 & 88 & 57 & 46 & 150 & 73 & 47 & 39 \\
\hline 10 & 256 & 123 & 79 & 64 & 189 & 91 & 59 & 48 & 156 & 76 & 49 & 41 \\
\hline
\end{tabular}

Source: Cohen, 1988 
APPENDIX C

Multicollinearity amongst exogenous variables.

\begin{tabular}{lll}
\hline Exogenous variable & Colinearity & \\
\hline & Tolerance & VIF \\
Product innovation & .799 & 1.252 \\
Process innovation & .456 & 2.195 \\
Marketing innovation & .413 & 2.423 \\
Organisational innovation & .510 & 1.961 \\
\hline
\end{tabular}

Source: Field work, 2014

APPENDIX D

Measurement model results

\begin{tabular}{lllllll}
\hline Latent & Indicators & $\begin{array}{l}\text { Loading } \\
\text { Variable }\end{array}$ & $\begin{array}{l}\text { Loadings } \\
\text { Squared }\end{array}$ & $\begin{array}{l}\text { Coefficient } \\
\text { Alpha }\end{array}$ & $\begin{array}{l}\text { Composite } \\
\text { Reliability }\end{array}$ & Ave \\
\hline APDINV & APDINV1 & 0.8724 & 0.7611 & 0.9144 & 0.9361 & 0.7462 \\
& APDINV2 & 0.7678 & 0.5895 & & & \\
& APDINV3 & 0.9143 & 0.8359 & & & \\
& APDINV4 & 0.8762 & 0.7677 & & & \\
BPCINV & APDINV5 & 0.8811 & 0.7763 & & & \\
& BPCINV1 & 0.7086 & 0.5021 & 0.8310 & 0.88103 & 0.5976 \\
& BPCINV2 & 0.8279 & 0.6854 & & & \\
& BPCINV3 & 0.7671 & 0.5884 & & & \\
& BPCINV4 & 0.7967 & 0.6347 & & & \\
CMKINV & BPCINV5 & 0.7597 & 0.5771 & & & \\
& CMKINV1 & 0.75 & 0.5625 & 0.8309 & 0.88105 & \\
& CMKINV2 & 0.7919 & 0.6271 & & & \\
& CMKINV3 & 0.7569 & 0.5729 & & & \\
& CMKINV4 & 0.8226 & 0.6767 & & & \\
& CMKINV5 & 0.74 & 0.5476 & & & \\
DOGINV & DOGINV1 & 0.781 & 0.6100 & 0.8268 & 0.87723 & \\
& DOGINV2 & 0.7984 & 0.6374 & & & \\
& DOGINV3 & 0.7606 & 0.5785 & & & \\
& DOGINV4 & 0.7287 & 0.5310 & & & \\
& DOGINV5 & 0.7654 & 0.5858 & & & \\
EOGPEF & EOGPEF1 & 0.6449 & 0.4158 & 0.8088 & 0.86116 & \\
& EOGPEF2 & 0.7195 & 0.5177 & & & \\
& EOGPEF3 & 0.7699 & 0.5927 & & & \\
& EOGPEF4 & 0.6675 & 0.4456 & & & \\
& EOGPEF5 & 0.7238 & 0.5239 & & & \\
& EOGPEF6 & 0.7483 & 0.5600 & & & \\
\hline
\end{tabular}


APPENDIX E

Cross loadings between the measures

\begin{tabular}{llllll}
\hline VARIABLE & APDINV & BPCINV & CMKINV & DOGINV & EOGPEF \\
\hline & & & & & \\
APDINV1 & 0.87244 & 0.36021 & 0.35094 & 0.33463 & 0.41309 \\
APDINV2 & 0.76782 & 0.28138 & 0.3223 & 0.27691 & 0.25094 \\
APDINV3 & 0.91434 & 0.36345 & 0.4044 & 0.36617 & 0.39508 \\
APDINV4 & 0.87624 & 0.35281 & 0.34108 & 0.32952 & 0.34111 \\
APDINV5 & 0.88108 & 0.34892 & 0.33125 & 0.31923 & 0.32294 \\
BPCINV1 & 0.37781 & 0.70865 & 0.49211 & 0.45567 & 0.42517 \\
BPCINV2 & 0.30212 & 0.82788 & 0.57576 & 0.57434 & 0.52551 \\
BPCINV3 & 0.2611 & 0.76715 & 0.49334 & 0.51547 & 0.41917 \\
BPCINV4 & 0.30659 & 0.79674 & 0.57855 & 0.43157 & 0.57662 \\
BPCINV5 & 0.29703 & 0.75968 & 0.58239 & 0.38974 & 0.47035 \\
CMKINV1 & 0.28142 & 0.51086 & 0.75003 & 0.49673 & 0.53201 \\
CMKINV2 & 0.29218 & 0.54789 & 0.79192 & 0.50879 & 0.47089 \\
CMKINV3 & 0.32161 & 0.4837 & 0.75689 & 0.5133 & 0.48634 \\
CMKINV4 & 0.30642 & 0.56686 & 0.82264 & 0.50248 & 0.54732 \\
CMKINV5 & 0.36891 & 0.61056 & 0.73997 & 0.53637 & 0.47384 \\
DOGINV1 & 0.38543 & 0.53389 & 0.57005 & 0.78104 & 0.51012 \\
DOGINV2 & 0.34561 & 0.57086 & 0.56960 & 0.79838 & 0.48254 \\
DOGINV3 & 0.35016 & 0.44743 & 0.43031 & 0.76055 & 0.43655 \\
DOGINV4 & 0.21105 & 0.34197 & 0.43829 & 0.72870 & 0.38302 \\
DOGINV5 & 0.11090 & 0.42150 & 0.50349 & 0.76537 & 0.43264 \\
EOGPEF1 & 0.22733 & 0.30170 & 0.43676 & 0.42821 & 0.64491 \\
EOGPEF2 & 0.34368 & 0.29069 & 0.40429 & 0.34332 & 0.71951 \\
EOGPEF3 & 0.36353 & 0.47174 & 0.49438 & 0.43242 & 0.76988 \\
EOGPEF4 & 0.19800 & 0.33343 & 0.41951 & 0.35238 & 0.66745 \\
EOGPEF5 & 0.28875 & 0.59023 & 0.49657 & 0.43405 & 0.72382 \\
EOGPEF6 & 0.30055 & 0.59707 & 0.51050 & 0.50758 & 0.74831 \\
\hline & & & & & \\
\hline
\end{tabular}

APPENDIX F

Fornell-Larcker criterion for checking discriminant validity

\begin{tabular}{llllll}
\hline VARIABLE & APDINV & BPCINV & CMKINV & DOGINV & EOGPEF \\
\hline APDINV & 0.86381 & & & & \\
BPCINV & 0.39739 & 0.77305 & & & \\
CMKINV & 0.40653 & 0.70438 & 0.7729 & & \\
DOGINV & 0.37878 & 0.61615 & 0.66203 & 0.76716 & \\
EOGPEF & 0.40537 & 0.62838 & 0.6508 & 0.59098 & 0.71364 \\
\hline
\end{tabular}

Note: Diagonal elements in bold = square root of AVE; Off-diagonal elements = correlation between constructs 


\section{APPENDIX G}

T- Values for outer model

\begin{tabular}{|c|c|c|c|c|c|}
\hline Indicator & $\begin{array}{l}\text { Product } \\
\text { Innovation }\end{array}$ & $\begin{array}{l}\text { Process } \\
\text { Innovation }\end{array}$ & $\begin{array}{l}\text { Marketing } \\
\text { Innovation }\end{array}$ & $\begin{array}{l}\text { Organisational } \\
\text { Innovation }\end{array}$ & $\begin{array}{l}\text { Organisational } \\
\text { Performance }\end{array}$ \\
\hline APDINV1 & 53.5614 & & & & \\
\hline APDINV2 & 22.4127 & & & & \\
\hline APDINV3 & 96.0167 & & & & \\
\hline APDINV4 & 49.9298 & & & & \\
\hline APDINV5 & 54.0186 & & & & \\
\hline BPCINV1 & & 19.1747 & & & \\
\hline BPCINV2 & & 43.3474 & & & \\
\hline BPCINV3 & & 22.1481 & & & \\
\hline BPCINV4 & & 30.0897 & & & \\
\hline BPCINV5 & & 22.6758 & & & \\
\hline CMKINV1 & & & 20.8050 & & \\
\hline CMKINV2 & & & 24.1773 & & \\
\hline CMKINV3 & & & 22.1517 & & \\
\hline CMKINV4 & & & 35.9396 & & \\
\hline CMKINV5 & & & 19.9851 & & \\
\hline DOGINV1 & & & & 29.4145 & \\
\hline DOGINV2 & & & & 33.2369 & \\
\hline DOGINV3 & & & & 19.0581 & \\
\hline DOGINV4 & & & & 17.9434 & \\
\hline DOGINV5 & & & & 21.9448 & \\
\hline EOGPEF1 & & & & & 14.3207 \\
\hline EOGPEF2 & & & & & 19.3758 \\
\hline EOGPEF3 & & & & & 21.1813 \\
\hline EOGPEF4 & & & & & 13.6678 \\
\hline EOGPEF5 & & & & & 21.0826 \\
\hline EOGPEF6 & & & & & 22.2384 \\
\hline
\end{tabular}

\section{APPENDIX H}

Structural model results for hypotheses 1, 2, 3 and 4

\begin{tabular}{lllll}
\hline Hypothesis & Beta & Std Error & t-value & $\mathbf{0 . 0 5}$ \\
\hline $\mathrm{H}_{1}$ APDINV / EOGPEF & 0.109 & 0.063 & 1.739 & Not Significant \\
$\mathrm{H}_{2}$ BPCINV / EOGPEF & 0.255 & 0.078 & 3.261 & Significant \\
$\mathrm{H}_{3}$ CMKINV / EOGPEF & 0.297 & 0.083 & 3.583 & Significant \\
$\mathrm{H}_{4}$ DOGINV / EOGPEF. & 0.196 & 0.083 & 2.348 & Significant \\
\hline
\end{tabular}

Source: Field Data, 2014

\section{APPENDIX I}

Predictive Relevance of the Independent Constructs

\begin{tabular}{ll}
\hline Latent variable & $\mathbf{Q}^{\mathbf{2}}$ \\
\hline $\mathrm{H}_{1}$ Product innovation. -> Organisational performance. & 0.2384 \\
$\mathrm{H}_{2}$ Process innovation. -> Organisational performance. & 0.2384 \\
$\mathrm{H}_{3}$ Marketing innovation-> Organisational performance. & 0.2384 \\
$\mathrm{H}_{4}$ Organisational innovation. -> Organisational performance. & 0.2384 \\
\hline
\end{tabular}

Source: Field Data, 2014 
Mensah, F. B., \& Acquah, I. S. K. (2015). The Effect of Innovation Types on the Performance of Small and Medium Sized enterprises in the SekondiTakoradi Metropolis. Archives of Business Research, 3(3), 77-98.

\section{APPENDIX J}

Summary of the effect size results.

\begin{tabular}{llllll}
\hline \multicolumn{2}{l}{ Latent variable } & $\mathbf{R}^{2}$ Included & $\begin{array}{l}\mathbf{R}^{2} \\
\text { Excluded }\end{array}$ & $\mathbf{f}^{2}$ & Assessment \\
\hline APDINV & EOGPEF & 0.5136 & 0.4990 & 0.0300 & Small \\
BPCINV & EOGPEF & 0.5136 & 0.5059 & 0.0158 & Small \\
CMKINV & EOGPEF & 0.5136 & 0.4807 & 0.0676 & Small \\
DOGINV & EOGPEF & 0.5136 & 0.4836 & 0.0617 & Small \\
\hline
\end{tabular}

Source: Field Data, 2014 